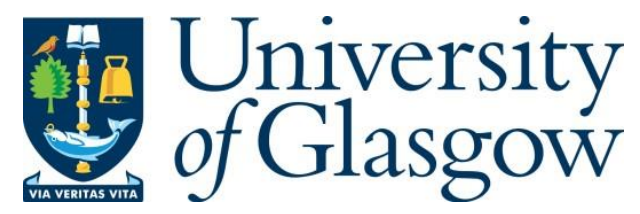

Palmer, V., Bowness, J. and Tulle, E. (2021) (Re)conceptualising physical activity participation as career. Ageing and Society, 41(4), pp. 936-954.

There may be differences between this version and the published version. You are advised to consult the publisher's version if you wish to cite from it.

http://eprints.gla.ac.uk/193459/

Deposited on: 20 August 2019

Enlighten - Research publications by members of the University of Glasgow http://eprints.gla.ac.uk 


\section{Reconceptualising physical activity participation as career}

\section{Abstract}

Physical activity is increasingly positioned as playing an important role in preventing and mitigating many of the decrements associated with biological ageing. As a result, public health messages encourage older people to remain active in later life. Despite this, physical activity participation rates among older adults are low. This may be in part related to the conventional approach to understanding physical activity participation as a product of motivation. We contend that this approach does not allow for a deeper exploration of the wider structural, historical and discursive contexts in which physical activity participation occurs. Therefore, we propose that physical activity can be reconceptualised as a career. Through a synthesis of findings from four studies exploring physical activity experiences in later life we demonstrate that beginning and maintaining a physical activity career requires a disposition towards physical activity, the legitimation of physically active practices, and dealing with contingencies. In addition, we demonstrate that maintaining a physical activity career requires investment and deliberation to continually adapt physical activity practices within an individual's own personal biography. As such, we conclude that current strategies to promote physical activity to older adults are unlikely to result in increased levels of participation. To promote physical activity to older adults an understanding of how structural, cultural and historical contexts influence participation is needed. 


\section{Reconceptualising physical activity participation as career}

\section{Introduction}

Evidence has been mounting that physical activity can play an important role in preventing and mitigating many of the decrements associated with biological ageing (Vina et al. 2016). As such, physical activity has become one of the key weapons in the fight against what is commonly known as the burden of ageing and meeting physical activity recommendations is now a key target of government strategies to improve health outcomes throughout the life course (WHO 2010; Department of Health 2011).

Statistics show that physical activity participation rates of older adults are low, which may suggest that people are less likely to take up or remain physically active as they get older (Hallal et al. 2012). We note that recent attempts to explain 'inactivity' focus on the determinants and correlates of physical activity, as well as barriers to its participation (Kosteli, Williams and Cumming 2016). These tend to focus on the individual, with rather superficial exploration of social factors. We would argue that this understanding of physical activity as a health-related behaviour masks the complex interplay of factors in which people's lives are conducted and decisions about their lives made. In the process this work risks reinforcing neoliberal public health discourse where individuals are expected to take responsibility for their health (Brown and Baker 2012). To overcome these deficits, we propose a different approach and conceptualisation. In what follows we present how the 'problem' of physical activity is constructed and dealt with in the literature. We then suggest that physical activity can be reconceptualised as a career whose emergence takes place within the structural, discursive and cultural features of society. This process involves the physical and emotional labour of learning to contend with one's body over one's lifetime, 
put to the test by a series of staging posts, twists and turns. The impact on identity is also considered. We will conclude with reflexions on the implications of this alternate approach to physical activity for our understandings of what it is like to be old in contemporary society.

Physical activity as lifestyle

In the latter half of the twentieth century our approach to the active body has been completely transformed. Since the 1980 s there has been an interesting confluence of two processes: research into the health benefits of physical activity as well as the increasing popularity of physical activities and the commodification of fitness (Maguire 2002). By the 1980 's there was a mass uptake of physically active pursuits such as running, cycling and club fitness (Tulle 2008; Maguire 2008; Stone 2004). As such, the fit body became an indicator of a successful (middle class) lifestyle (Howell and Ingham 2001). At policy level, the teaching of physical activity in schools shifted its focus to encouraging lifelong participation (Green 2002).

On the science side, increasing volumes of epidemiological research from the 1990s onwards have linked physical activity with various markers of physical and mental health (see for example Bauman 2004; Warburton, Nicol and Bredin 2006). This prompted the development of physical activity guidelines which provided recommended levels of physical activity to achieve health benefits and placed physical activity at the forefront of public health policy throughout the developed world. Since their first iteration in the US in 1995, physical activity guidelines have been updated, amended and revisited in line with scientific discoveries (e.g. WHO 2010; Department of Health 2011). Nevertheless, global figures 
suggest that one third of adults do not meet current recommended levels of physical activity (Hallal et al. 2012).

In response to this, research turned to developing interventions that would get people active. Reinforcing neoliberal ideology, that one should take responsibility for one's health, these tended to target inactivity at an individual level. Popular models, such as the environmental (Thompson, Aspinall and Roe 2014) and ecological models (Owen et al. 2010), recognise that individual behaviour needs to be understood within a broader framework, taking account of the social, policy and physical context in which people make decisions. However, these tend to place the individual at the nexus of concentric circles of influences. What prevails is a deficit model according to which individuals are blamed for their failure to meet official physical activity recommendations (e.g. WHO 2010; ChodzkoZajko et al. 2009). By implication this failure of motivation is cast as a constitutive characteristic of older age, and by extension, older people. Furthermore, the tone of the literature is mostly exhortative, adopting a stick and carrot approach. The stick is the risk of falling, disease or obesity and the carrot the promise of better health, restored function and improved well-being. Thus, interventions tend to target the motivation deficit among older people (Clark 1999). The carrot is clearly not appealing enough, and to make it more enticing experimentations with a range of incitements to physical activity, largely advice, monitoring and the promise of company and even enjoyment are promoted (Spirduso, Francis and MacRae 2005).

So far, there has been little evidence that interventions informed by these models are effective at population level. Long-term adherence remains problematic (van der Bij, Laurant and Wensing 2002; Hawley-Hague et al. 2016: Pettigrew et al. 2018). As Foster et al. 
(2005) noted, most interventions last no longer than 12 months, meaning that their impact on long term engagement in physical activity is relatively unknown. The unusual context of PA interventions also leads to questions regarding what happens post-intervention, with some questioning the ecological validity of existing findings (Hagger and Weed 2019). In addition, physical activity interventions have produced mixed findings, with Heath et al., (2012) and Artinian et al., (2010) noting that interventions are culturally determined. This emphasises the importance of acknowledging the wider social and cultural context in which physical activity occurs. Yet very few interventions have explored these.

To understand the processes involved in 'being active' there is a need to shift the focus away from individual motivation (Pheonix and Bell 2018) and take seriously the broader context in which physically active practices occur. Bercovitz (2000: 24) has argued that "the 'problem' of sedentarianism" is socially constructed, with ideas about what it means to be active dictated by what scientific data is deemed important by researchers at the time. In addition, variation in the measurement of physical activity (self-report vs objective) also raises questions about the validity of claims about population activity levels. It appears that, to be considered 'active' individuals must meet the recommended guidelines. Thus, across the world people may be active, just not 'active enough'.

Currently, social scientists have taken up the mantle of critically evaluating existing knowledge on health promotion (Dionigi and Gard 2018). The evidence from the social sciences is that we should understand physical activity as a social practice embedded in a nexus of factors, including the different social worlds in which people live their lives, which promote or limit physical activity (Guell et al 2016). Furthermore, as others have argued (Phoenix and Orr, 2017; Phoenix and Bell, 2018), how we move our bodies in later life is 
subjected to fluctuations driven by a confluence of factors: the activities themselves and their physical demands, the weather, life events, caring responsibilities, a range of external factors and of course the vagaries of the body itself. Fluctuations in what they refer to as 'the possibility of movement' are the result of different rhythms coming into contact (rhythms of life, of ageing bodies (see also Nettleton 2013), of the activities themselves, of the external world) and demanding responses. These writers show clearly that a key feature of our capacity and our inclination to move is that it is unstable and precarious, prone to interruptions. Thus negotiating physical activity as a healthy practice is complex, a balancing act with other health practices (e.g. eating and drinking), rather than a simple, linear engagement in response to the exhortation to be more active. PA occurs as people negotiate their roles and relationships as they age. This can facilitate as well as hinder. Meaning can be found in PA in different ways. We agree with Phoenix and Orr (2017) that we must go beyond ideas around motivation and healthy lifestyle.

We want to add to this rich scholarship in several ways: our focus will be on the life course, bringing to the fore the affordances or threats to physical activity, whether it starts early in the life course or late (Griffin 2017). We will also take the longer historical range into consideration the conditions in which people put themselves into movement. What seems normative behaviour or normal embodiment at a point in time can become deviant later and vice versa (Eichberg 2011). What we want to draw attention to is that we are subjected to synchronic and diachronic forces which cut across time and shape how we envisage our lives being led as we age and how we live in and with our bodies. Therefore, to deal with these complex processes, we propose using the concept of 'career' as a heuristic device to uncover these forces and the vagaries of physical activity engagement across the life course. 


\section{The Complexities of Career Making}

The concept of career has been used in sociology, including in the field of sport. Our own reworking of the concept of career includes processes which need to be made more explicit than has previously been done so that we can understand the conditions in which a successful career is more likely emerge and develop. For this we are influenced by Boudieusian sociology as it provides us with the opportunity to focus on the embodied nature of physical movement and the structural and cultural context in which careers can be allowed to emerge, both as initial disposition and as a practice that develops over time. Physical activity can be understood as a social field because as Bourdieu (1984) has shown, the propensity to be physically active has a class orientation. It also reflects norms associated with gender (Semerjian 2018), age (Palmer, Tulle and Bowness 2018) and ethnicity (Victor 2018), influencing whether and how we take part in physical activity. Thus, individuals are embedded in a range of norms with which they must contend. Furthermore physical activity engages with the body. The body can be conceptualised as physical capital (Bourdieu 1978), because it manifests the value conferred on different body types as well as being an entity on which to work to acquire value. The latter infers a level of instrumental reflexivity on the part of social actors (for instance wishing to lose weight or to become more muscular) as a practice of social distinction that demonstrates one's social location. The propensity to deploy such instrumental rationality is worthy of investigation. The body is also where our social location or habitus is made manifest through the internalisation of dispositions during socialisation. Dispositions inflect our orientation to our body, both in the choices we are more likely to make to put it in movement and how we come to sense it. At this point, we need to acknowledge the agency of the social actor (his or her ability to make individual decisions); and the historical but also biographical effects which modulate 
life trajectories. These considerations, as has been argued by others such as Alexander (1995), are not well accounted for in Bourdieu's theoretical framework. Bourdieu does show that our social location affects our dispositions for social action. But this does not necessarily account for how people deal with social change nor with how people contend with demands for them to change their dispositions (Tulle 2017) or how they justify their practices (Boltanski and Thevenot 2006). This is what we mean when we posit that our dispositions to physical activity lie at the confluence of diachronic and synchronic forces (Palmer, Tulle and Bowness 2018; Tulle 2017). The concept of career enables us to bridge the gap between structure and agency.

In its original formulation the concept of career captures the objective as well as subjective aspects of occupation (Becker 1963; Faulkner 1974; Braude 1975). Subjective careers involve the individual's movement through their own biography (McHugh 1968); constituting what Becker (1952) highlights as horizontal movement, one in which subjective experience can change without a change in objective career markers such as rank or income.

In sport, the concept of career has been fruitfully used by Stevenson $(1990 ; 2002)$ to understand the socialisation of elite athletes into sporting competition. This work is a reminder that sport is akin to an occupation, with pay scales, a status hierarchy and rules which operate vertically over time. The occupational setting itself acts as a culture from which athletes derive their identity. Thus, athletes are subjected to a process of 'conversion'. Moving from professional sport to sport as a leisure pursuit, Stebbins (2014: 4) coined the concept of serious leisure which he defines as 'the systematic pursuit of an amateur, hobbyist, or volunteer activity'. As well as identifying three types of leisure careers 
(amateur, hobbyist, volunteer), Stebbins (2014: 28) describes how the use of serious leisure leads to the creation of a 'fulfilment career', one which develops alongside a changing relationship to leisure activities. An individual may progress from a 'dabbler' to a 'devotee', travelling through a 'leisure career' (Stebbins 2014: 37). In conjunction with this process a 'subjective career' emerges (McHugh, 1968). This work demonstrates that the concept of career can be applied to non-remunerated activities where an emphasis is on vertical progression as the dabbler progresses to devotee. What is also implied is that careers have an objective start and end, often beginning in youth and ending in retirement from participation.

In considering the physical activity careers of older people we can look to research on Masters sport. The accounts of Stevenson (2002) and Heuser (2005) demonstrate some of the similarities that Master athlete careers share with younger athletic careers. For example, the stages of both types of career involved an introduction to the sport and a process of identification with the sport. However, their work also highlights the substantially different context in which these careers begin and evolve. As Stevenson (2002) notes, Masters athletes had to engage in 'seekership' to find their sport, whilst Heuser (2005) demonstrates that Masters lawn ballers faced physical retirement but not social retirement. When exploring participation in Masters sport, Dionigi (2015) refers to different trajectories with some 'continuers' playing sport their whole life, other participants exhibiting a more intermittent relationship to sport and physical activity, or yet others who begin participating late in life. Henaff-Pineau (2018) has demonstrated how engagement in physical activity reflects prevalent forms of socialisation into normative embodiment, gender norms, public policy and life course norms. We have also previously identified physical activity 
participation as functional, sporting or performative in relation to the different meanings that social actors themselves attach to their practice (Palmer, Tulle and Bowness 2018). What is emerging is that physical activity careers can take a variety of forms.

Our theoretical synthesis enables us to unlock questions to help capture the complexities and ambiguities of physical activity participation. For if one emanates from a social location that does not encourage the development of certain dispositions, what would be the conditions for these dispositions to be acquired at another point in the life course when norms of physicality are changing which might coincide with the time that the body itself loses physical capital? Are they the same dispositions? How does one then progress from disposition to a sustained engagement with the type of physical capital that inheres in that physical activity practice? How is that engagement achieved in practice? Therefore, conceptualising the accomplishment of physical activity as a career which takes place in a specific social, cultural and historical context which has become favourable to it has prompted the following research questions:

How do people embed the disposition to be physically active and how do they maintain it across the lifecourse?

How has the recent reconstruction of physical activity as a health behaviour affected people's dispositions and actual practices?

\section{Methodology}

The analysis presented below is drawn from four studies by Tulle (2008; Tulle and Dorrer 2012), Palmer (2015) and Bowness (2017) (summarised in Table 1). Each study explored older adults' experiences of being physically active. Studies 1 and 4 included social actors 
who had successfully become physically active and had remained so over several years,

whilst studies 2 and 3 include people whose PA practices had lapsed or exhibited wide fluctuations. The wide age range in Studies 1 and 4 can be explained by the fact that entry into Master sport is set at age 40. These informants are chronologically still relatively young. However, they are deemed too old to take part in mainstream sport and are therefore forced to contend with physiological ageing.

\begin{tabular}{|c|c|c|c|c|}
\hline & Tulle (2008) & $\begin{array}{c}\text { Tulle and Dorrer } \\
\text { (2012) }\end{array}$ & $\begin{array}{l}\text { Palmer } \\
(2015)\end{array}$ & Bowness (2017) \\
\hline Study I.D & Study 1 & Study 2 & Study 3 & Study 4 \\
\hline $\begin{array}{l}\text { Number of } \\
\text { participants }\end{array}$ & 21 & 15 & 5 & 19 \\
\hline Age range & $48-86$ & $55-83$ & $59-79$ & $40-75$ \\
\hline $\begin{array}{l}\text { Physical } \\
\text { Activity } \\
\text { Participatio } \\
\text { n }\end{array}$ & Master Runners & $\begin{array}{l}\text { Limited or no } \\
\text { experience of } \\
\text { physical activity in } \\
\text { early lifecourse }\end{array}$ & $\begin{array}{c}\text { Mixed levels } \\
\text { and types of } \\
\text { participatio } \\
\mathrm{n}\end{array}$ & $\begin{array}{c}\text { Masters Highland } \\
\text { Games Athletes }\end{array}$ \\
\hline $\begin{array}{l}\text { Guiding } \\
\text { research } \\
\text { questions }\end{array}$ & $\begin{array}{l}\text { How did Master } \\
\text { runners enter and } \\
\text { remain in their } \\
\text { sport over time? } \\
\text { How did they } \\
\text { manage bodily } \\
\text { ageing? }\end{array}$ & $\begin{array}{l}\text { What are the } \\
\text { experiences of } \\
\text { older adult's who } \\
\text { become regular } \\
\text { exercises in a gym } \\
\text { following health } \\
\text { problems? }\end{array}$ & $\begin{array}{l}\text { How are } \\
\text { dispositions } \\
\text { towards } \\
\text { physical } \\
\text { activity } \\
\text { created and } \\
\text { reproduced } \\
\text { within } \\
\text { families? }\end{array}$ & $\begin{array}{l}\text { What are the } \\
\text { experiences of } \\
\text { ageing men and } \\
\text { women in the } \\
\text { Masters Highland } \\
\text { Games? }\end{array}$ \\
\hline $\begin{array}{l}\text { Period of } \\
\text { data } \\
\text { collection }\end{array}$ & 2000 & 2010 & 2011 & 2014- 2016 \\
\hline $\begin{array}{l}\text { Methods of } \\
\text { data } \\
\text { collection }\end{array}$ & $\begin{array}{c}\text { Participant } \\
\text { observations at } \\
\text { club sessions and } \\
\text { life-history } \\
\text { interviews with } 14 \\
\text { men and } 7 \\
\text { women }\end{array}$ & $\begin{array}{c}\text { Life history } \\
\text { Interviews with } \\
\text { older men and } \\
\text { women (15), } \\
\text { Interviews with } \\
\text { gym staff (3) }\end{array}$ & $\begin{array}{c}\text { Life history } \\
\text { Interviews, } \\
\text { PA } \\
\text { Monitoring } \\
\text { (activPAL), } \\
\text { Group } \\
\text { Interviews }\end{array}$ & $\begin{array}{c}\text { Life history } \\
\text { interviews, In } \\
\text { person, } \\
\text { and by Email, } \\
\text { Participant } \\
\text { Observations at } \\
\text { Highland Games } \\
\text { event }\end{array}$ \\
\hline $\begin{array}{l}\text { Method of } \\
\text { data } \\
\text { analysis }\end{array}$ & $\begin{array}{l}\text { Recreation of } \\
\text { biographies and } \\
\text { Interpretive }\end{array}$ & $\begin{array}{c}\text { Interpretive } \\
\text { Phenomenologica } \\
\text { I Analysis }\end{array}$ & $\begin{array}{c}\text { Inductive } \\
\text { Thematic } \\
\text { Analysis + } \\
\text { Descriptive }\end{array}$ & $\begin{array}{c}\text { Interpretive } \\
\text { Phenomenologica } \\
\text { I Analysis }\end{array}$ \\
\hline
\end{tabular}




\begin{tabular}{|l|c|l|c|}
\hline & $\begin{array}{c}\text { Phenomenologica } \\
\text { I Analysis }\end{array}$ & $\begin{array}{c}\text { Statistics of } \\
\text { activPAL } \\
\text { data }\end{array}$ & \\
\hline
\end{tabular}

By using four sources of data, each including its own sub-cultural logic of practice, we aim to reveal the complexities of becoming physically active and the fragility of maintaining a physical activity career. In all four projects life-history interviews were used to reflect on the process of becoming physically active (Plummer 2001, Tulle 2008) identifying personal, emotional and embodied dimensions of being active or otherwise. What makes our approach to life history interviews distinctive is they were also designed to bring to light the broader, i.e. structural, context in which the urge to be physically active or the resistance to physical activity had arisen.

Analysis of each dataset took place within an interpretivist epistemology with the focus on making visible underlying structures as they were manifested in the accounts and claims of research participants (Silverman 2013). We brought together the individuals' biographies and physical activity careers that we had recreated before we began this process of analytical and theoretical synthesis.

The process of recreating biographies in each study had proved remarkably productive, drawing our attention to 'career contingencies' (Prus and Irini 1980) that older adults must negotiate to maintain a physical activity career throughout the life course. For the current analysis we compared biographies across the four studies to see whether we could detect the triggers and barriers to the achievement of a longstanding physical activity career across distinctive samples. We then returned to the transcripts to map out the social, cultural and structural forces which enabled these careers to emerge and develop, or in some instances 
to remain undeveloped. Our discussions synthesised the findings of each study, producing thematic similarities but also demonstrating exceptional cases (as in the work of Pheonix and Orr 2017). This process roughly follows what Heidegger (1927) referred to as the 'hermeneutic circle', a process by which the interpretation of smaller parts adds to a collective whole. This involved a back and forth between emergent themes, significant exceptions and case study specific nuance. From our synthetic analysis three themes or career processes were identified: 1 . Discovery and athletic awakening, 2. Remaining in the field as reflexive practice and 3 . The materiality of a physical activity career.

\section{Findings}

Discovery and athletic awakening

Often, the first contact with physical activity occurs in childhood through play or PE. However, as Stevenson (1999: 82) points out, "just because someone is introduced to a sport, or indeed any sort of involvement, it does not mean that they will necessary or inevitably become committed to it". Nevertheless, early experiences of being physically active can shape dispositions to physical activity that endure throughout the life course. These early experiences can lay the foundations of a physical activity career, as the experiences of this man and woman from Study 3 illustrate:

Donald: Eh it's gone with me all through my life really, I mean when I go back to school where there was a lot of physical activity and I've been in various clubs of one kind and another which has involved some physical activity, eh as the years have gone on it has dwindled [sigh] $(\mathrm{M}, 68)$ 
Mary: I love dancing I've always loved dancing em....when I was young I was very sporty swimming...you know running tennis netball and that was the school of course but eh I normally was very active anyway. $(F, 71)$

These early experiences equipped these informants with a degree of physical capital needed to undertake a wide range of sports. They also provided them with a phenomenological understanding of what it feels like to put the body into movement, which may be an important influence in continuing or returning to physical activity later in life. However, not everyone has positive early experiences of physical activity in early life, as a woman from Study 4 exemplifies:

Do you have any history of sports when you were younger? Say at school or?

Anna: Nope, I was the fat girl who always got picked last in gym class, I hate to say that but that's what it was, but I do not have that background in athletics at all. (F, 47)

Anna's experience shows how low levels of physical capital at school meant that her initial engagement with physical activity was negative, with peers failing to value the physical capabilities of those not exhibiting symbolically valued bodies. In contrast to Donald and Mary, Anna lacked physical competency, with lifelong consequences on her own perceived capability to be active. Physical competency can therefore act to legitimise practice, which can turn an initial encounter with sport or physical activity into a more solid disposition to be active. Commensurately, the absence of physical competency may deter the creation of a PA disposition. 
For some, such as Elaine (Study 3, F, 62), who walks regularly, there is no clear initiation as she claims: I've always just walked everywhere. Others note how their social class shaped their sport participation. For example, working class men had to contend with restricted spaces of legitimation. Thus, as a working-class lad, Harry (Study 1), who did not start running until the age of 35 , does not recall being able to find physical expression in athletics:

running never actually took off until the TV because I don't know anybody that done 1500 metres and ... it is just... for a working person [my emphasis] it was always football. It is sad when you think about it. I mean there must have been a lot of kids that were fast runners, but they didn't go to the right school and get the right education. ( $M, 55)$

Women have also encountered barriers. Betty (Study 1 ) engaged in track and field as a youngster but early on encountered restrictions in how much effort she could legitimately display:

Cross country at that time was not a long, long distance. It is quite interesting to see how women are now allowed to run... I mean I have indeed run a marathon but how you are allowed to run a marathon now because when I was young the most that we were allowed to run was three and a half miles. So that was long distance for me. $(F, 67)$ Not only do people have to have an encounter with an activity, the context in which this activity acts as a space of legitimation is also important. In the above example, the club provides a safe space for people to train and develop their practice, but it can also reflect and rehearse stereotypes about women's physical strength. In addition, these clubs themselves also reflect the prevailing class structure, thus Betty came from a middle-class 
habitus. The track and field female athletes in Study 1 demonstrate that they were only able to pursue a physical activity career because of the coming together of a range of factors manifested in one key attribute: the possession of 'natural aptitude' (Tulle 2008), which predisposed them to sport and competence but also had to be kept in check. Athletics was the perfect locale for natural aptitude to be displayed appropriately. Working class female bodies had no such space of legitimation in which their natural aptitude could be discovered (Tulle and Dorrer 2012; Tulle 2018).

Despite negative experiences in childhood Anna (Study 4) eventually found a pathway to sport later in life:

So how did you first get started?

Anna: Erm, got into Facebook there was a Facebook conversation going on and somebody got into a conversation about the Highland Stillhouse Pub back home in Oregon, and one of the guys was an athlete, make sure you come watch us at the Portland Highland Games, and I went and watched and was working out and doing some stuff, why don't you come throw with us. "I can't do that, why would I do that", he convinced me to start throwing so I started practicing with some of the people who were on this field today, and they've become amazing friends and wonderful teachers and very patient with those of us who are not the best athletes already anyway. $(F, 47)$

In Anna's case, her early experiences and lack of physical capital continued to influence her perceived ability to be an active person. She needed favourable conditions to become a 'late bloomer' (Dionigi 2015) namely, a more empowering social environment, the support of peers, the discovery of physical capital and, we surmise, a certain amount of deliberation. 
Remaining in the field as reflexive praxis

Physical activity careers tend to form a winding path rather than a clear trajectory, and they are contingent. They must occur within the context of everyday life, working around family and occupational roles that change as life progresses. They are also modulated by wider social structures. Very few participants reported uninterrupted physical activity careers, with participants across all studies describing the dropping in and out of physical activities across their lives. Breaks and transitions were highly contextual. For example, one Highland Games athlete (Study 4) described the specific situation that led to his return to Masters sport:

Barry: I was a Division III college shot-putter and won a couple of conference titles and a state championship. I threw until I was roughly 26 , competing in various meets around the east. I was good, but far from great. When I turned 40 , a recently graduated thrower from my alma mater contacted me and asked me why I stopped throwing and if I would be interested in throwing again. I was recently divorced, and without a whole lot of entertainment funds, so I took him up on his offer, and we started to train hammer throw together.... I then discovered Masters Track and Field, and competed in those meets, including the indoor and outdoor national championships. $(\mathrm{M}, 47)$

Barry had a long gap in his sporting career. His return to sport and his transition to Highland Games were facilitated by others, but also required a personal commitment to re-engage a disposition towards sport. Many participants in Studies 2, 3, and 4 described breaks in their physical activity careers that corresponded with major changes in their lives, such as having 
children, getting married, retirement, or as they got older - caring for/loss of a spouse.

Donald (Study 3) demonstrates this well:

I was exceptionally fit then and that continued through into the start of my working life I was in a judo club and did a fair bit of hill walking so I had all that going on...and then I got married! So, it's my wife's fault [laughs] no since then again pressures of work the time just wasn't there and if I did have any time I wanted to chill out I didn't want to do exercise and I just became lazier it's as simple as that $(M, 68)$

Returning to these physical practices, or new ones, requires an act of deliberation to reignite a disposition towards such activities. Other participants spoke about the changing nature of physical activity as they wrestled with competing demands of work and family life, and how this had changed over the years. For example, some with active jobs meant that they felt a loss of physical activity when they retired and sought out new opportunities to be active. Similar to the findings of Dionigi, Fraser-Thomas and Logan (2012), family life also shaped physical activity practices, with many of the participants describing how raising a family involved being active with their children. In some cases, as a child's physical activity developed, the importance of a parent's physical activity became secondary, as exemplified in Jacob's account (Study 4):

My family is all supportive of my athletic endeavours. When the kids were younger, they attended all of my games. Now that they are coming into their own, we often have to split up for all of our individual contests. I try to put them before myself as they are young and impressionable. I do not want them to think I find my activities more important than theirs. For this reason, I see my involvement in the future of $H G$ 's being reduced somewhat to accommodate the increase in their activity. I think I 
will always continue to strive for the Master's World Championships as long as I am able to throw. That is much more than a great competition, but an opportunity to see friends of mine from all over the world at least once a year. $(M, 45)$

Whilst often posing as a barrier to physical activity careers, (grand)children occasionally provided a new opportunity to be active. Elaine (Study 3) explains:

obviously when the children were younger you'd be playing more football or running around the park with them or going for a race with them or something like that, but I still do it with the grandchildren now you know so it keeps me going $(F, 62)$

Elaine's engagement with physical activity was intricately tied into her family structure. These barriers can prove challenging to a physical activity career in later life. Yet many do continue in sport and physical activity in a variety of guises. For those engaged in Masters sport, parenting poses a competing logic to that of a particular sport. In Jacob (Study 4) and Donald's (Study 3) cases, the logic of being a good father or husband challenged the specific logic of their involvement in the Highland Games, Judo or hill walking. To be successful at managing both, a reflexive approach that juggles occupational and parental obligations, as well as the ageing body, is required. The ageing of the body, both physiologically and phenomenologically, can also affect physical activity careers.

\section{The materiality of a physical activity career}

Alongside the changing roles along the life course encountered above, the body itself must be contended with. Physiological ageing, injuries and illness occupy a noteworthy but rarely highlighted place in the shaping and durability of physical activity careers. They can place the sporting or physical activity career at risk by forcing retirement or at the very least a 
substantial shift in activity. Our findings suggest different situations: $i$. the discovery of new modes of training that enable them to prolong their career fruitfully, ii. having to consider major changes, perhaps even retirement, and iii. taking up physical activity following illhealth.

Elspeth's (Study 1) training was transformed as she has got older. Far from slowing down, she has begun incorporating weight training as an act of injury prevention and bodily maintenance. This contrasts with the light touch training she had been brought up with:

Well it has improved... it is getting harder actually! I mean I started off... I never... I did no weights at all at that time, I would do running. I would do a lot of my running on the machine in the winter, so I would do longer runs. You know on the machine instead of going out. And then I would do sprints and hill runs. As I say a lot of it is running and then I would come down to the track and do the runs, but it has gradually increased. I mean I started weights last year, last winter and I was doing structured runs on the machine [...] I am doing a lot of weights and a lot of running but I am doing hill running and fartlek runs. It is a lot of stress endurance stuff at the moment and then down at the track I am doing reps... you know so... $(F, 59$,

Elspeth has become a reflexive actor, calling upon expertise to help quantify the body and organise a regime of self-intervention. Another example comes from Matthew (Study 4):

more and more so I have less and less pain as I compete but again as I've gotten older I spend less and less time lifting heavy weights pushing and I spend more and more time massaging stretching honouring my body, so I go after more quality of 
movement don't push myself for force generation, does that make sense you know as an athlete you know what I'm saying $(M, 51)$

Both athletes engage in bodily reflexivity to ward off potential issues, a process that Rich and Miah (2017: 87) refers to as 'rendering the body knowable'. However, this is not possible for all athletes and many are faced with major changes. Ben (Study 1), a longdistance runner, was diagnosed with arrhythmia and could no longer run for long periods of time. This has forced him to move to orienteering:

You know I have got a problem and I have accepted that. It is something that is going to limit what I do athletically. $(M, 58)$

For Charlotte (Study 4), emergent injury problems have led her swap activity:

Errm since I have consulted a little bit more about the knee, knowing what the treatment algorithm is, my knee is not in any way to me a candidate for surgery for a knee replacement or anything like that, my back has had better days, [...] it probably was a factor in me moving away from powerlifting, I say I have retired from powerlifting again for me the fun factor wasn't there right now and that's why I officiate at it, so I can stay with the sport and I don't have to feel as though I have to beat myself up training for it $[\ldots](F, 56$,

Thus, in both cases sport itself provides people with an element of agency that can help mitigate the disappointments of having to retire by offering alternatives modes of engagement to protect identity. Outside of the confines of the logic of sport, this can become trickier. Norrie (Study 2), had a long history of athletics and sport, including 
representing his country in track and field. Later in life he was diagnosed with osteoarthritis in both ankles. He therefore sought help with this, to contain the pain but also in the hope that he could maintain some of his physical activities, such as hillwalking. The diagnosis and the pain made him quite depressed. His help-seeking brought little comfort:

Norrie: [...] and then one day they said, 'well we can't do anything more for you, we can't do anything more for you'. They would just send me off.

ET: Do they know that you are physically active and stuff like that. Was that of interest to them?

Norrie: No, they didn't care. (M, 71)

The health care professional provided little support to salvage some of his physical activity career. He was therefore left to his own devices to find ways of coping with his condition. In general, all the research participants who had forged a long career and had developed high levels of physical capital were committed to remaining in the field of athletics in one form or another, some operating on the border between symptom management and exacerbation. A strong identification with the field appeared to be necessary to overcome the fragility of the body brought on by injury or illness. When this is missing the career can become even more precarious.

For the physically active grandparents interviewed in Study 3, health was deeply embedded in their physical activity experiences. Indeed, for some it was a primary reason for participating. An example comes from Jim (Study 3):

I would just think physical activity is relating to health at the end of the day and I think physical activity is a must in everybody's life (M, 79) 
However, the terms of their participation are quite different to those of the athletes we have highlighted above. For many of the older grandparents in Study 3, the focus on health was related to their own prior experiences. Two men had been 'prescribed' physical activity for heart conditions. Doing physical activity whilst experiencing health issues had its own demands, as Donald (Study 3) points out:

Donald: [...] I was put into a cardiac exercise class, which finished and then they promoted me to one on a Monday night which is much more aerobic. $(M, 68)$ VP: Mmhmm

Donald: And I'm finding that very tough, being overweight doesn't help but eh with the arthritis in the joints and that is a painful experience.

For Graeme (Study 2) it is the fear of over-exertion which led him to refuse to comply with the demands by the gym instructors of working at a specific heart rate:

Nika: You think you might be doing yourself some damage?

Graeme: Well I do believe that you can overwork as well as not work at all. $(M, 75)$

Being physically active to prolong life does not on its own provide the logic of bodily maintenance that sport does: it does not address the issue of pain, the fear of over-exertion or as Phoenix and Bell (2018) noted the rhythms of the body in response to pain, tiredness or mood.

\section{Discussion}

This paper aimed to demonstrate that physical activity can be reconceptualised as a career. We were prompted to do this by the apparent failure to increase physical participation rates among older people as informed by largely health-focused, approaches to low physical 
activity participation among older adults. We contend that the health imperative in physical activity risks encouraging promises about ill-health and ageing which are unfulfillable, precisely because the level of physical engagement required to prolong life, and prevent illhealth, is not easily within reach. Becoming and remaining physically active in later life is a process which is much more complex and fragile than has been made evident in some of the biomedical literature. By synthesising data from four datasets we captured the experiences of those who have successfully embedded sport or physical activity in their lives as well as those of others who are finding it more difficult to do so or to maintain a regular physical activity practice. This allowed us to identify the key components (dispositions, legitimation and contingencies) of physical activity careers, uncovering the work required by older adults to engage in physical activity practice at levels which would match or exceed current guidelines.

The concept of career is not meant to be normative: it is a heuristic device which makes explicit what it takes to become and remain physically active. Previous research (HenaffPineau 2009; Dionigi 2015; Palmer, Tulle and Bowness 2018) has shown that becoming and remaining physically active takes many forms and can take place at different points across the life course. However, typologies of physical activity in later life overlook the dynamic processes which enable these different modalities to emerge, on a day to day basis as Phoenix and Bell (2018) have shown and over a longer range. Utilising the concept of career, we can unpack the conditions in which an individual is physically active and how these are mediated by the structural, discursive, cultural and historical features of society, as well as temporality and embodiment. We suggest that a physical activity career is rarely linear or stable, and unlike athletic careers, for example, the goal itself is not always particularly clear in advance. Nevertheless, as one develops a physical activity career there 
are notable stages, namely: the development of dispositions towards being active;

legitimation of practice and dealing with contingencies.

Beginning a physical activity career is not straightforward. Like Stevenson (2002) and Heuser's (2005) description of athletic careers, an introduction to physical activity will not necessarily result in a physical activity career. Individuals must have or develop a disposition towards being active. The latter, as we have demonstrated, may be influenced by class, gender or age and are key to an individual's 'deepening engagement' (Stevenson 2002) with physical activity practices. Despite this, a disposition alone may not even be enough for a career to flourish. Physical activity practices must be viewed as a legitimate practice, which may be reinforced through for example clubs, sporting sub-cultures, or public health messages.

Once a physical activity career is established, maintaining it requires work and we argue, deliberation. Physical activity must be reconciled within people's everyday lives. These 'career contingencies' (Prus and Irini 1980) act as barriers that require the development of reflexive capacities that allow an individual to negotiate life changes and maintain an identification with a specific practice. Meaning that at different points of the career physical activity practices must be reinforced as legitimate. For those whose physical activity practices related to their identity and were immersed in sporting sub-cultures this process was less complex as they found legitimation in the logic of practice itself (Bourdieu 1984). Nevertheless, they still needed a reflexive approach to practice.

This reflexive approach to career contingencies also applies to the body. A physical activity career requires a functioning body to begin with. Injuries and illness pose a threat to functionality. The knowledge of one's body is often attached to the logic of a specific practice. For example, runners explored body management techniques that allowed them to 
continue running. But the older active person also must manage changes in their body as they age. The ageing body is itself a career contingency that requires a reflexive approach. Just as Bourdieu's work (1978; 1984; 1993) recognises class-based differences in orientations towards the body, we recognise that ageing can contribute to changing orientations to the body, most notably through an increased self-awareness of the body's fragility. Therefore, maintaining a physical activity career requires a cultivation of the body, one that fosters an instrumental relationship to the body. That is, the physically active body becomes a body of rigid discipline.

These acts of self-discipline may find legitimation in the promotion of physical activity for older adults within a public health discourse. For some of our participants, health featured prominently in their accounts. However, it is worth noting that those who discussed being active for health did so based on their own personal experiences of ill health and they placed barriers on how much effort they were prepared to submit themselves to. For older adults with longstanding physical activity careers, health was not a primary reason for remaining active; in fact, some of the older athletes resisted the public health discourse. Finally, the historical conditions in which we develop a physical activity dispositions alter over time and within our lifetime. The challenge is not just to get started but to adapt or reinterpret our practice to our own unspooling biographies as they themselves are continually shaped by changing norms and values. Thus, an early disposition to physical activity has proven useful for some (by recognising oneself as physically adept early on in life). The reconstruction of sport and physical activity as a health-giving practice in their adult lives can provide legitimacy for pursuing sport into later life. This historical shift may facilitate 
access for women who had been socialised in times when normative feminine embodiment privileged passivity. Older individuals may also find legitimacy in health promotional discourses that challenge negative stereotypes about ageing. But we found that health is not a sufficient condition for sustained participation unless there is a willingness to submit oneself to the disciplining inherent to the practice itself over a long period of time (logic of practice), thus transcending the health imperative. Ironically this disciplining of the body can be at odds with persistent social and cultural norms. In other words, shedding these normative constraints is a lifelong process of negotiation. Motivation is thus not simply a property of the individual, but an outcome of being integrated in the logic of practice.

\section{Conclusion}

What emerges from our reflexions is that sustained physical activity participation is not that different from sport participation in its requirements that participants enter a logic of practice which provides legitimation and ultimately leaves an imprint on identity. In turn the health imperative which drives the turn to physical activity has helped reconstruct sport as more than athletic endeavour, thus helping prolong sporting careers. Physical activity as a health-related practice has helped transform norms of embodiment, especially among older men and women, acting as a new imaginary of old age. It has also produced new spaces for pleasure and enjoyment (Phoenix and Orr, 2015). However, fulfilling WHO recommendations on physical activity requires an investment of time, a deliberate, timeconsuming and disciplinary orientation to the body which is akin to an emergent form of life (Rose 2007). It is precisely the temporality of physical activity which makes it vulnerable to 
interruptions, the materiality of changed embodiment, the vagaries of life and historical change.

Thus, we argue that current arrangements to promote physical activity as a new form of life are unlikely to yield increased physical activity participation in a short period of time. If we consider individual variations in dispositional capital, we conclude that what is needed is a correspondingly rich offering in physical activity initiatives which reconstruct movement as liberation from culturally enforced passivity and from alienated embodiment. This conclusion chimes with that of Boulton, Horne and Todd (2017), who call for a plurality of practices offered to older adults. We are also inspired by an orientation to physical activity that treats the person as 'a subject with a personal and situated body that should be used to manage and develop one's emotional life' (Svendsen and Svendsen 2017: 489). We also need to recognise the limitations of the promise of physical activity - physical activity is about risk reduction. It is not a substitute for addressing the structural factors which produce health and age inequalities. Lastly, we need to respect immobility among those whose choice it is, either as an intellectual or existential positioning.

\section{Statement of funding}

The original research projects which contributed to this analysis was funded by doctoral funding from Glasgow Caledonian University (Studies 1, 3 and 4) and the Nuffield Foundation (Study 2).

\section{Declaration of contribution}

All contributors have made an equal contribution to the writing of this paper. 


\section{Statement of conflict of interest}

None to report

\section{Acknowledgements}

Our thanks go to the anonymous reviewers' whose evaluations led us to improve this paper.

\section{References}

Alexander JC (1995) Fin de siècle social theory. London: Verso.

Artinian NT, Fletcher GF, Mozaffarian D, Kris-Etherton P, Van Horn L, Lichtenstein AH and Meininger JC (2010) Interventions to promote physical activity and dietary lifestyle changes for cardiovascular risk factor reduction in adults. A scientific statement from the American Heart Association. Circulation, 122: 406-41

Bauman AE (2004) Updating the evidence that physical activity is good for health: an epidemiological review 2000-2003. Journal of Science and Medicine in Sport, 7, 6-19. Becker HS (1952) The career of the Chicago public schoolteacher. American Journal of Sociology, 57, 470-77.

Becker HS (1963) Outsiders: Studies in the Sociology of Deviance. New York: Free Press Bercovitz KL (2000) A critical analysis of Canada's 'Active Living': Science or politics? Critical Public Health, 10 , 19-39.

Boltanski L and Thévenot L (2006) On justification: Economies of worth. Trans C. Porter. Princeton: Princeton University Press.

Boulton ER, Horne M, Todd C. (2018) Multiple influences on participating in physical activity in older age: Developing a social ecological approach. Health Expectations. 21:239-48. 
Bourdieu P (1978) Sport and social class. Information (International Social Science Council), $17,819-840$.

Bourdieu P (1984) Distinction: A social critique of the judgment of taste. trans. R Nice.

Cambridge, MA: Harvard University Press.

Bourdieu P (1993) The field of cultural production: Essays on art and literature. Columbia University Press.

Bowness J (2017) Physical activity in later life: a phenomenology of ageing men and women in the Masters Highland Games. Unpublished PhD Thesis, Glasgow: Glasgow Caledonian University.

Braude L (1975) Work and Workers: A Sociological Analysis. New York: Praeger Brown BJ and Baker S (2012). Responsible citizens: Individuals, health, and policy under neoliberalism. London : Anthem Press.

Burlot F and Lefèvre B (2009) Le sport et les seniors: des pratiques spécifiques? Retraite et Société, 2, 133-58.

Chodzko-Zajko WJ, Proctor DN, Singh MAF, Minson CT, Nigg CR, Salem GJ and Skinner JS (2009) Exercise and physical activity for older adults. Medicine \& Science in Sports \& Exercise, 41, 1510-30.

Clark DO (1999) Physical activity and its correlates among urban primary care patients aged 55 years or older. The Journals of Gerontology Series B: Psychological Sciences and Social Sciences, 54, S41-48.

Department of Health and Social Care (2011) UK physical activity guidelines. Waterloo, UK: Department of Health and Social Care 
Dionigi RA (2015) Pathways to Masters Sport: Sharing Stories from Sport 'Continuers', 'Rekindlers' and 'Late Bloomers'. In Phoenix, C and Tulle, E. (eds) Physical Activity and Sport in Later Life (pp. 54-68). Basingstoke: Palgrave Macmillan UK.

Dionigi RA, Fraser-Thomas J, Logan J (2012) The nature of family influences on sport participation in Masters athletes. Annals of leisure research. 15:366-88.

Dionigi, RA and Gard, M. (2018) Sport and Physical Activity across the Lifespan. Springer.

Faulkner RR (1974) Coming of age in organizations: A comparative study of career contingencies and adult socialization. Sociology of Work and Occupations, 1, 131-73.

Foster C, Hillsdon M, Thorogood M, Kaur A and Wedatilake T (2005) Interventions for promoting physical activity (Review). The Cochrane Database of Systematic Reviews, 1, Art. No.: CD003180. DOI: 10.1002/14651858.CD003180.pub2

Griffin M (2017) Embodied learning and new physical activity in mid-and later life. Qualitative Research in Sport, Exercise and Health, 9, 554-67.

Guell C, Shefer G, Griffin S, et al. (2016) 'Keeping your body and mind active': an ethnographic study of aspirations for healthy ageing. BMJ, 6: e009973. doi:10.1136/ bmjopen-2015-009973 Hagger MS and Weed M (2019) Do Interventions Based on Behavioral Theory Work in the Real World? International Journal of Behavioural Nutrition and Physical Activity Hallal P, Andersen L, Bull F, Guthold R, Haskell W and Ekelund U (2012) Global physical activity levels: surveillance progress, pitfalls, and prospects. The Lancet, 380, 247-57. 
Hawley-Hague H, Horne M, Skelton DA and Todd C (2016) Older adults' uptake and adherence to exercise classes: instructors' perspectives. Journal of Aging and Physical Activity, 24, 119-28.

Heath GW, Parra DC, Sarmiento OL, Andersen LB, Owen N, Goenke S and Lancet Physical Activity Series Working Group. (2012). Evidence-based intervention in physical activity: lessons from around the world. The Lancet, 380, 272-81.

Hénaff-Pineau PC (2009) Vieillissement et pratiques sportives: entre modération et intensification. Lien social et Politique, 62, 71-83.

Hénaff-Pineau PC (2018) L'adaptation de la pratique des sportifs du grand âge: objet de négociations. Gérontologie et Société, 40, 111-26.

Heuser L (2005) We're not too old to play sports: The career of women lawn bowlers. Leisure Studies, 24, 45-60.

Howell J and Ingham A (2001) From social problem to personal issue: The language of lifestyle. Cultural Studies, 15, 326-51.

Kosteli MC, Williams SE and Cumming J (2016). Investigating the psychosocial determinants of physical activity in older adults: a qualitative approach. Psychology \& health, 31, 730-749 Maguire JS (2002) Body lessons: fitness publishing and the cultural production of the fitness consumer. International Review for the Sociology of Sport, 37, 449-64.

Maguire JS (2008) Leisure and the obligation of self-work: An examination of the fitness field. Leisure Studies, 27, 59-75.

McHugh P (1968) Defining the Situation the Organization of Meaning in Social Interaction. Indianapolis, Bobbs-Merrill. 
Nettleton S. (2013) Cementing relations within a sporting field: Fell running in the English Lake District and the acquisition of existential capital. Cultural sociology. $7: 196-210$. Owen N, Healy GN, Matthews CE and Dunstan DW (2010) Too much sitting: the populationhealth science of sedentary behavior. Exercise and Sport Sciences Reviews, 38, 105. Palmer V (2015) The negotiation of physical activity in three generational families. Unpublished PhD Thesis, Glasgow Caledonian University Palmer VJ, Tulle E and Bowness J (2018) Physical Activity and the Ageing Body. In The Palgrave Handbook of Ageing and Physical Activity Promotion (pp. 531-549). Basingstoke: Palgrave Macmillan.

Pettigrew S, Burton E, Farrier K, Hill A, Bainbridge L, Airey P, Lewins G and Hill K (2018) Encouraging older people to engage in resistance training: A multi-stakeholder perspective. Ageing and Society, 1-20. doi:10.1017/S0144686X1800034X Phoenix P and Bell SL (2018) Beyond "Move More": Feeling the Rhythms of physical activity in mid and later-life, Social Science \& Medicine, DOI: 10.1016/j.socscimed.2018.05.006. Phoenix C and Orr N (2014) Pleasure: A forgotten dimension of physical activity in older age. Social science \& medicine. 115:94-102.

Phoenix C and Orr N (2017) Analysing exceptions within qualitative data: promoting analytical diversity to advance knowledge of ageing and physical activity. Qualitative research in sport, exercise and health. 9:271-84

Plummer K (2001) Documents of life 2: an invitation to a critical humanism. London: Sage Publications.

Prus RC and Irini S (1980) Hookers, rounders, and desk clerks: The social organization of the hotel community. Toronto: Gage Publishing. 
Rich E and Miah A (2017) Mobile, wearable and ingestible health technologies: towards a critical research agenda. Health Sociology Review, 26, 84-97. Green K (2002) Lifelong Participation, Physical Education and the Work of Ken Roberts, Sport, Education and Society, 7, 167-182, DOI: 10.1080/1357332022000018850 Rose N (2007) Beyond medicalisation. The Lancet, 369, 700-02. Semerjian TZ (2018) The Role of Gender and Social Class in Physical Activity in Later Life. In The Palgrave Handbook of Ageing and Physical Activity Promotion (pp. 571-588). Basingstoke: Palgrave Macmillan.

Silverman D (2013) Doing qualitative research: A practical handbook. SAGE Publications Limited.

Spirduso WW, Francis KL and MacRae PG (2005) Physical dimensions of aging. Champaign, IL: Human kinetics. American Journal of Human Biology, 18, 275-87.

Stebbins R (2014) Careers in serious leisure: From dabbler to devotee in search of fulfilment. Basingstoke: Palgrave Macmillan.

Stevenson CL (1990) The athletic career: Some contingencies of sport specialization. Journal of Sport Behavior, 13, 103.

Stevenson, CL (1999). Becoming an elite international athlete: Making decisions about identity. In Coakley, J., Donnelly, P. (eds), Inside sport (pp86-95). London: Routledge Stevenson CL (2002) Seeking identities: Towards an understanding of the athletic careers of masters swimmers. International Review for the Sociology of Sport, 37, 131-46. Stone WJ (2004) Physical activity and health: Becoming mainstream. Complementary Health Practice Review, 9, 118-128. 
Svendsen, A M and Svendsen, JT (2017) Contesting discourses about physical education: A critical discourse analysis of 20 textbooks used in physical education teacher education in Denmark, European Physical Education Review, 23, 480-498.

Thompson CW, Aspinall P and Roe J (2014) Access to green space in disadvantaged urban communities: evidence of salutogenic effects based on biomarker and self-report measures of wellbeing. Procedia-Social and Behavioral Sciences, 153, 10-22.

Tulle E (2008) Ageing, the body and social change: Running in later life. London: Palgrave MacMillan

Tulle E (2017) Becoming a hillwalker: incorporating history in understandings of physical activity. Qualitative Research in Sport, Exercise and Health, 9, 170-82.

Tulle E (2018) Une nouvelle forme de vie? Reconstruire le corps vieillissant par l'activité physique. Gérontologie et Société, 40, 95-110.

Tulle E and Dorrer N (2012) Back from the brink: ageing, exercise and health in a small gym. Ageing and Society, 32, 1106-27

Van Der Bij AK, Laurant MG and Wensing M (2002) Effectiveness of physical activity interventions for older adults: a review1. American Journal of Preventive Medicine, 22, 12033.

Victor C (2018) Physical Activity Amongst Ethnic Minority Elders: The Experience of Great Britain. In The Palgrave Handbook of Ageing and Physical Activity Promotion (pp. 589-605). Basingstoke: Palgrave Macmillan.

Viña J, Rodriguez-Mañas L, Salvador-Pascual A, Tarazona-Santabalbina FJ, and GomezCabrera MC (2016) Exercise: the lifelong supplement for healthy ageing and slowing down the onset of frailty. The Journal of Physiology, 594, 1989-1999. 
Warburton DE, Nicol CW and Bredin SS (2006) Health benefits of physical activity: the evidence. Canadian Medical Association Journal, 174, 801-09.

World Health Organisation (2010) Global recommendations on physical activity for health. Geneva: WHO. 